\title{
The Role of Distance Education in Economic Growth and Development: Developing a Model
}

\author{
Hossein Najafi, ${ }^{1,}$ Mohammad Ali Javadi Bura, ${ }^{2}$ and Mehran Farajollahi ${ }^{3}$ \\ ${ }^{1}$ Associate Professor, Distance Education Planning, Department of Education, Payame Noor University, Tehran, Iran \\ ${ }^{2}$ Associate Professor, Distance Education Planning, Department of Education, Farhangian University, Mazandaran, Iran \\ ${ }^{3}$ Assistant Professor, Education Department, Payame Noor University, Tehran, Iran \\ "Corresponding author: Hossein Najafi, Associate Professor, Distance Education Planning, Department of Education, Payame Noor University, Tehran, Iran, E-mail: \\ hossien_najafi@pnu.ac.ir
}

Received 2015 July 19; Revised 2016 March 19; Accepted 2016 March 26.

\begin{abstract}
Background: In this is age of technology distance education serves individuals by enhancing their knowledge, attitude, skills, and behavior; it can also be a significant driver of economic development. The purpose of this research was to examine the role of distance education in economic development in Payame Noor University (PNU).

Methods: From a total population of 1238 PNU students, a sample set of 184 was made randomly using Cochran's formula. Data were collected using a 33-item distance education questionnaire and a 23-item economic development scale, both of which were developed by the researchers. Chronbach's alpha determinations were 0.857 and 0.825 for these 2 instruments respectively. Data were analyzed using the Pearson correlation in SPSS structural equation modeling in LISREL.

Results: Results showed a significant positive correlation (0.438) between distance education and economic development. Distance education was also significantly correlated with average (0.218) and high (0.441) economic development. Goodness of fit indices showed that the model was a good fit to the data $\left(\chi^{2} / \mathrm{df}=0.764 ; \mathrm{RMSEA}=0.002 ; \mathrm{GFI}=0.97 ; \mathrm{AGFI}=0.93\right)$.

Conclusions: Based on the present findings, optimal and culturally adjusted ICT application in education can increase efficiency in many important measures of economic development such as effectiveness, productivity and capital deepening.
\end{abstract}

Keywords: Technology, Distance Education, Economic Development, Factor Analysis

\section{Background}

This is the age of technology. Technology describes innovative tools for, selection, adoption, adaption and application of task functions or problem solving (1). Applied to human resources, technology is manifestation of tacit knowledge (2). Technology can be used to acquire, create, disseminate, process, apply and transfer knowledge within a minimum timeframe and at low cost (3). It can also be effective in promoting literacy and knowledge. Distance education has emerged from increasing application of technology in education (4-6).

Technology is an essential component of distance education. Distance education can overcome the shortcomings of conventional education systems due to characteristics such as temporal and spatial separation of the delivery/learning process, decentralized student and learning support and more effective student-teacher-content interactions (7). It can also play a crucial role in economic development by lowering costs of education while increasing its effectiveness, efficiency, capital intensity, productivity and employment; considerations that serve to improve the quality of life (8). Distance education refers to the use of ICT, multimedia and electronic devices to design, create and manage the teaching-learning process to achieve continuous improvement and learning (9).

The modern age is characterized by economic globalization and the creation of novel ideas. Economic development requires investment in human resources and this can be done through distance education that develops knowledge, attitude, skills and behavior $(10,11)$. Economists have highlighted the importance of training as a type of investment. In the early 1960s, economics of education emerged as an autonomous field to study the economic issues related to education as well as the role of education in economic development (12). Psacharopoulos examined education in terms of cost-effectiveness in 32 countries and found that the return on an investment in education was higher than returns on physical capital (13).

Human resource development can bring about profound changes and open up opportunities in the global economy. Tjaden reports that economic development can be achieved through investment in education (14). Distance education can play a crucial role in increasing productivity and efficiency of human resources and by contributing to economic development (15).

Investing in education technologies can create ad- 


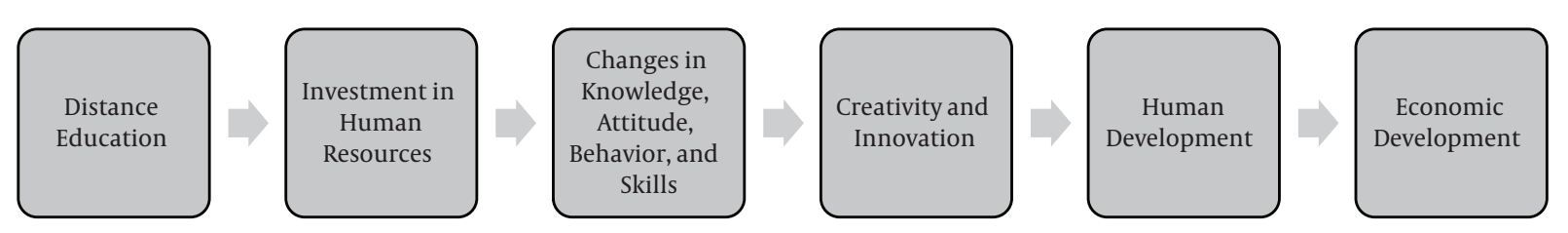

Figure 1. A Model for Translating Education Technology Into Efficiency, Effectiveness, and Productivity in the Process of Economic Development (15)

vanced universities capable of training highly specialized and creative human capital. These better-educated individuals then enter the labor market with higher levels of efficiency, productivity and innovation thus contributing to a variety of economic activities that facilitate economic development on a national scale. This then allows for more investment in universities and the process repeats itself (15).

According to Figure 2, economic development requires investment into human resource development, thereby universities are a prime targets for this type of investment. However, in the technological age of the 21st century, traditional education alone can no longer meet the needs of new generations. Education experts in UNESCO have advocated that the pursuit of technology is one of the most important factors in development, especially economic development. Distance education is one such technology that is has recently received much research attention. In 1997, OECD member countries invested about 7 percent of their GDP in distance education (16). Top countries in the field of knowledge creation (United States, Japan, and Germany) are the biggest exporters of advanced technologies. Therefore, the use of technologies in education is an important factor in economic development and should not be overlooked (17).

Most economists believe that ICT and educational technologies are at the core of current changes and development (18). Research has shown that a modern economy is one characterized by increasing globalization (deregulation, expansion of global markets and competition) as well as technological advances. Accordingly, diffusion of ICT improves business practice, generates spillover benefits and raises productivity throughout the economy (19). In the United States and some other advanced or developing countries, production and use of educational technologies and e-learning tools have led to increased productivity and economic growth $(20,21)$. It has been well established that ICT contributes to economic growth and to labor and multi-factor productivity (22). The technology of distance education can foster creativity and innovation and reduce education costs. It can also contribute to economic growth through capital deepening and reorganization of capital in the design, preparation, and production phases of web-based educational content (23). Distance education can solve problems associated with shortages of specialized workforce and reduce costs of multimedia and ICT (24). Increased capacity for the creation of knowledge has lowered costs for hardware and software; use of SCORM-based learning management systems and contents allows for building optimal information systems and facilitates access to educational content. The possibility of delivering content to different parts of the world provides easy access to content that lays the foundation for implementation of e-government, e-commerce and e-learning (11).

Incentives such as lower education costs and faculty salaries, increased revenue from admissions of large numbers of virtual students and enhanced productivity of elearners have encouraged educational institutions to invest in distance education, which in turn contributes to the creation of new manufacturing and service industries in an economy (11). Distance education technology can design and produce educational content at low cost, increase the creation of knowledge and aid productivity, these considerations all have a positive effect on production, earnings, investment and employment (23).

Distance education technology has a significant effect on the costs of coordinating economic activities in institutions (Figure 3). In this figure, A indicates multimedia goods (distance education technology). The left-hand side of the figure represents production of educational content or the supply side, while the right-hand side represents demand (demand for content). Thus, multimedia are critical to production, presentation and consumption of educational content. In the production function F; physical capital, human capital and human resources are represented by $\mathrm{K}, \mathrm{H}$, and $\mathrm{N}$ respectively. In the utility function $\mathrm{U}$; letters $\mathrm{A}$ and $\mathrm{C}$ indicate basic consumer goods. In this new economic structure, multimedia goods contribute to economic growth (25).

Rena reports that distance education plays a crucial role in economic growth and development by increasing workforce productivity and enabling a workforce to use more advanced technology (26).

Nour reports a positive correlation between ICT expenditure and economic development in Egypt and the Gulf 


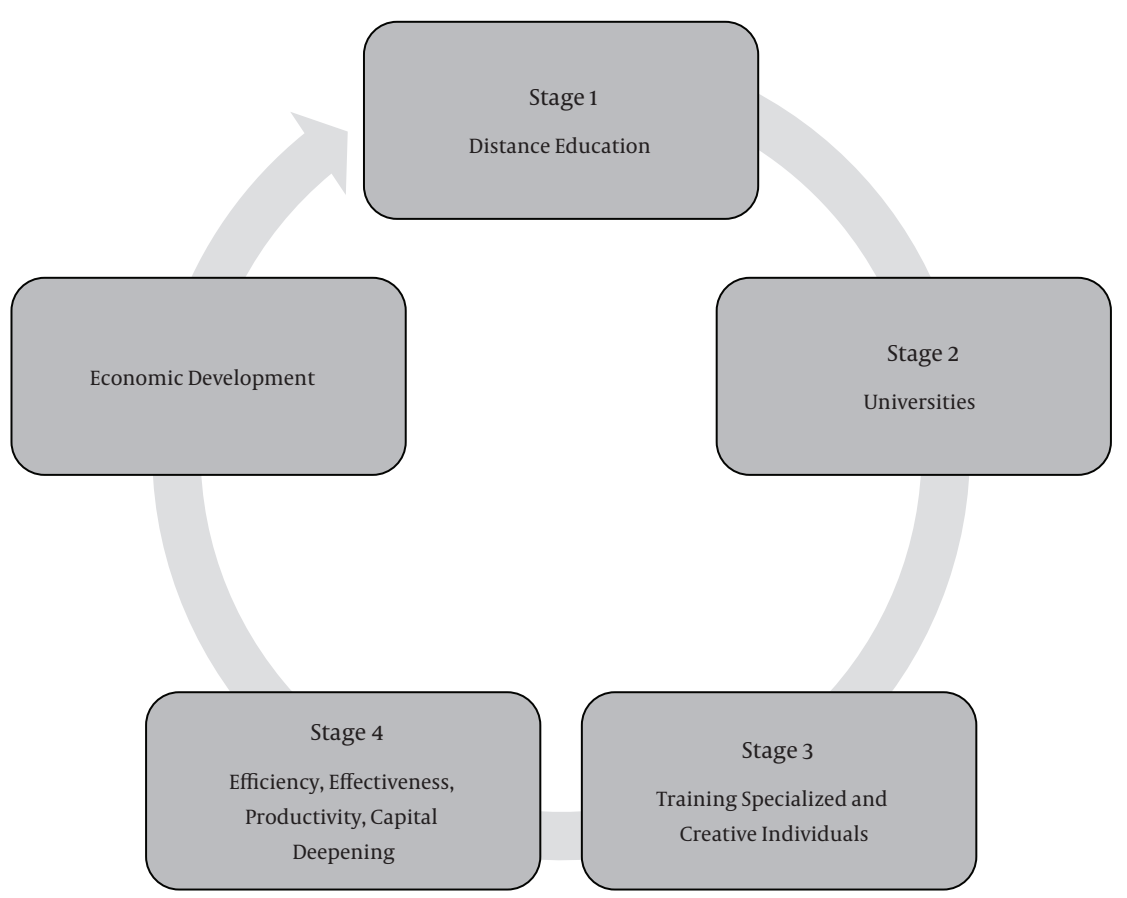

Figure 2. The Relationship Between Universities, Human Capital, Economic Activities and Economic Development (15)

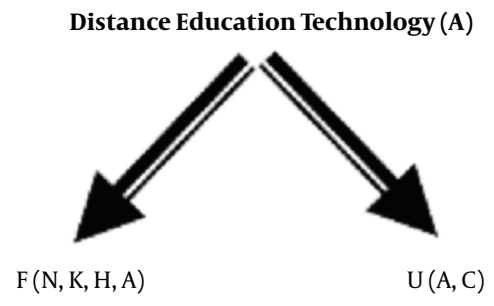

Figure 3. The New Economy and the Role of Distance Education Technology (25)

States. The research also demonstrated that ICT diffusion had a positive correlation to economic growth and human capital/education (27). Haacker and Morsink argued that IT contributes to growing labor productivity by increasing levels of IT capital per worker and total factor productivity (TFP). The research showed that both IT production and expenditure had a significant effect on acceleration of TFP (28). Schreyer showed that ICT capital goods were important contributors to economic growth in G7 countries (24). Kodres found that TFP and labor productivity were affected by advanced ICT (29). Najafi et al., argued that distance education reduced education costs and the need for a full-time faculty and that it motivated students to embark on a path of lifelong learning as well as contributing to increased efficiency, effectiveness and productivity thus contributing to economic growth and development (11). The present research aimed to determine whether or not there was a significant relationship between distance education technology and economic development, and if so, whether that relationship was strong, moderate or weak. The study also aimed to determine the effect of distance education technology on economic development using a model.

\section{Methods}

This research was a done as a descriptive survey. The population consisted of $1238 \mathrm{PhD}$ students of Payame Noor University (PNU) during the second semester of 2012 - 2013. Based on Cochran's formula, 184 students were randomly selected as the sample. PNU was selected for the study due to it being a leading Iranian University in ICT and distance education. Data were collected using a 33-item distance education questionnaire with 3 subscales (technology, interaction and facilities) and a 23-item economic development scale with 4 subscales (efficiency, effectiveness, productivity and capital deepening) and 23 items. These items were rated on a 5-point Likert scale. Economic development was examined at three levels: high, average and low. Content 
validity of the instrument was verified by a panel of experts. Moreover, Chronbach's alpha was used to examine reliability of the instruments. An alpha of 0.857 was obtained for distance education questionnaire and an alpha of 0.825 was obtained for the economic development scale. Data were analyzed in SPSS and LISREL using Pearson correlation and structural equation modeling.

The variables were as follows:

1- Independent variable: Distance education consisted of three components, namely technology, interaction and facilities. Technology included multimedia, e-books, learning content management systems, SCORM model for content production, the Internet, intranets and extranets, videoconferencing, scientific databases, E-mail, ICT and hypertexts and hyperlinks. Interactions included teacherlearner, teacher-teacher, teacher-content, learner-learner, learner-content, content-content and learner-interface. Facilities included attention to individual differences, attention to education quality and quantity, easy and timely access to educational content, attraction of working with computers and multimedia, greater effort in a Web-based environment, detailed planning and needs' assessments, education support systems, learner autonomy, equal learning opportunities, ability to transcend time and space, application of education, lower cost education, investment in human resources, learner self-assessment and comprehensive and up-to-date content.

2- Dependent variables: Economic development consisted of four components: efficiency, effectiveness, productivity and capital deepening. Efficiency included reduced costs, increased production, improved product quality, labor productivity and capital productivity. Effectiveness included environmental impact of services, availability of services to the public, customer trust and improved social conditions. Productivity included customer satisfaction, flexibility, meeting targets, quality of working life, continuous improvement in output-to-input ratio and increased quality. Capital deepening included capital per worker, capital market integration, resource allocation, risk management, and facilitating trade.

\section{Results}

Pearson correlation was used to examine the relationship between distance education technology and economic development.

These results indicated that at 99\% confidence level, there was a significant correlation between distance education technology and economic development $(r=0.438)$. The correlation between distance education technology and high, average and low economic development was also examined.
These results indicated that at 99\% confidence level, distance education technology was strongly correlated with high economic development $(\mathrm{r}=0.441 ; \mathrm{P}=0.000)$ ( Table 3).

These results indicated at $99 \%$ confidence level, that distance education technology was moderately correlated with average economic development $(\mathrm{r}=0.218 ; \mathrm{P}=0.000)$ (Table 4).

These results indicated at 99\% confidence level, no significant correlation between distance education technology and low economic development $(\mathrm{r}=0.112 ; \mathrm{P}=0.04)(\mathrm{Ta}-$ ble 5).

\subsection{Structural Equation Modeling}

Structural equation modeling (SEM) was used to determine whether or not there was a causal relationship between distance education technology and economic development.

The Chi-squared for the proposed model with degree of freedom at 16 was evaluated at 12.32, not statistically significant $(\mathrm{P}=0.25)$. Thus, the Chi-squared test confirms that the model was a good fit to data. Moreover, the $\chi^{2} / \mathrm{df}$ ratio was 0.774. Although this index is not a universally agreed upon measure of a good or a bad fitting model, a lower value indicates a better fit. It must be noted that $\chi^{2}$ is highly sensitive to sample size and this may sometimes affect the results. The Goodness of Fit Index (GFI) is a measure of fit between a model and the observed covariance matrix. A GFI evaluation closer to 1 indicates a better fit of the model. In the proposed model, GFI was determined at 0.97 , indicating that the model was a good fit to the data. The root mean square error of approximation (RMSEA) was evaluated at 0.0033 , and its $90 \%$ confidence interval was between 0.33 and 0.45 . RMSEA ranged from 0 to 1 , with smaller values indicating a better fit. In addition, the adjusted goodness of fit index (AGFI) was evaluated at 0.93, indicating that the model was a good fit.

Figure 4 shows that the model was a good fit to the data: $\chi 2 / \mathrm{df}=0.764$ (less than 3); RMSEA $=0.002$ (less than $0.01)$; GFI $=0.97$ (greater than 0.90); AGFI $=0.93$ (greater than 0.90); Sig. = 0.12 (greater than 0.05). Thus, there was a causal relationship between distance education and economic development.

\section{Discussion}

In this age of information, increasing demand for university admissions and high costs and shortcomings of traditional education requires new approaches such as distance education. The purpose of the present research 
Table 1. Reliability of the Instruments

\begin{tabular}{|c|c|c|c|c|}
\hline \multirow[t]{2}{*}{ Instrument } & \multirow[t]{2}{*}{ Number of Items } & \multicolumn{3}{|c|}{ Cronbach's Alpha } \\
\hline & & Subscale & & Total \\
\hline \multirow{3}{*}{ Distance Education } & \multirow{3}{*}{33} & Technology & 0.83 & \multirow{3}{*}{0.85} \\
\hline & & Interaction & 0.89 & \\
\hline & & Facilities & 0.84 & \\
\hline \multirow{4}{*}{ Economic Development } & \multirow{4}{*}{23} & Efficiency & 0.83 & \multirow{4}{*}{0.82} \\
\hline & & Effectiveness & 0.81 & \\
\hline & & Productivity & 0.84 & \\
\hline & & Capital Deepening & 0.81 & \\
\hline
\end{tabular}

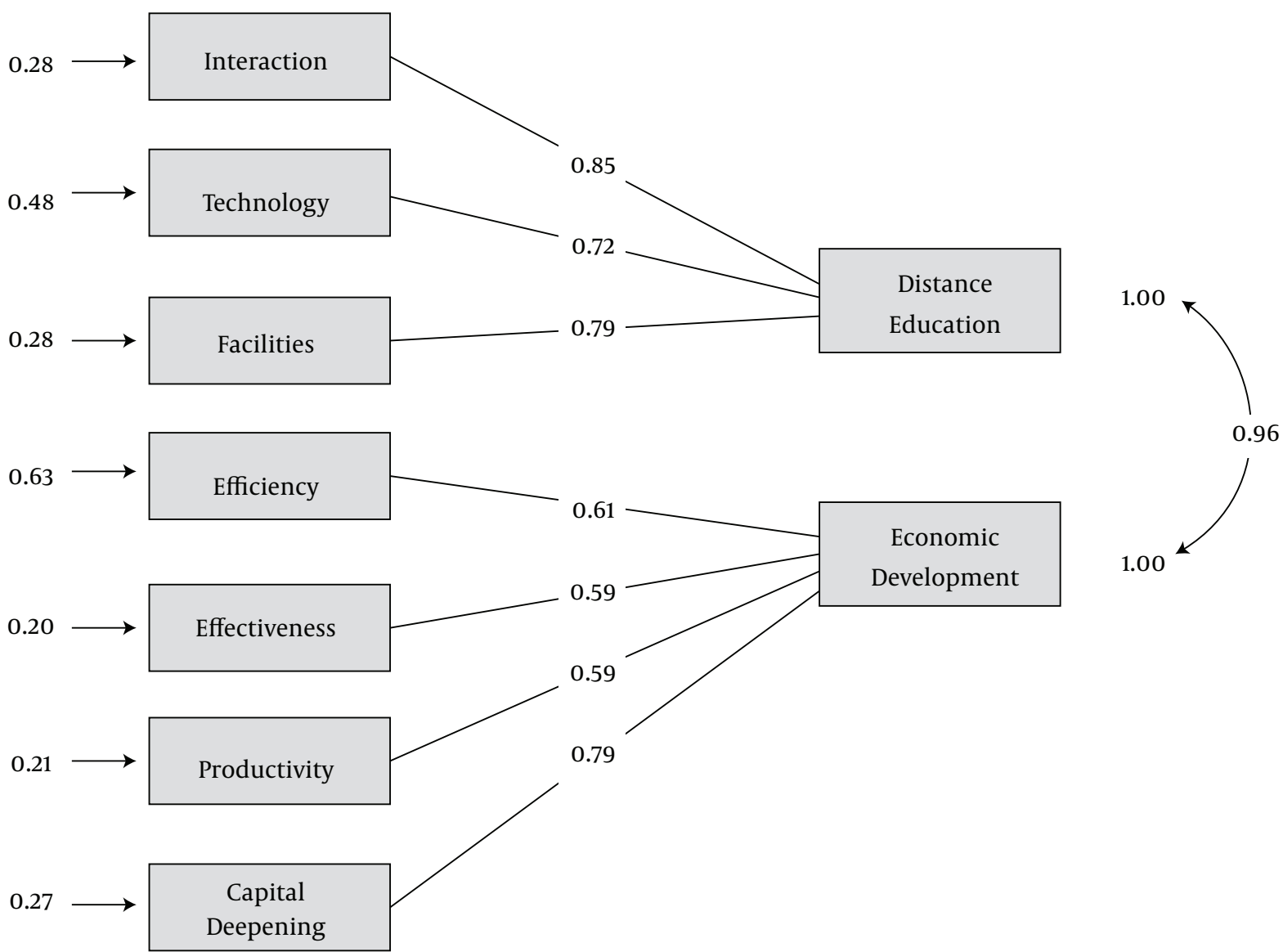

Chi-Square $=12.32, \mathrm{df}=16, \mathrm{p}=$ VAlue $=0.12$, RMSEA $=0.12$, RMSEA $=0.002$

Figure 4. The Proposed Structural Equation Model

was to examine the relationship between distance education and economic development. Results showed that dis- tance education had a significant role in economic development by increasing efficiency, effectiveness, productiv- 
Table 2. Distance Education Technology and Economic Development

\begin{tabular}{lccc}
\hline Variable & No. & Pearson Correlation & Sig. \\
\hline Economic Development & 184 & 0.43 & $<0.001$ \\
\hline & & & \\
\hline \hline
\end{tabular}

Table 3. Distance Education Technology and High Economic Development

\begin{tabular}{lccc}
\hline Variable & No. & Pearson Correlation & Sig. \\
\hline High economic development & 184 & 0.44 & $<0.001$ \\
\hline & & & \\
\hline
\end{tabular}

Table 4. Distance Education Technology and Average Economic Development

\begin{tabular}{lccc}
\hline Variable & No. & Pearson Correlation & Sig. \\
\hline $\begin{array}{l}\text { Average economic } \\
\text { development }\end{array}$ & 184 & 0.21 & $<0.001$ \\
\hline & & & \\
\hline
\end{tabular}

Table 5. Distance Education Technology and Average Economic Development

\begin{tabular}{|c|c|c|c|}
\hline Variable & No. & Pearson Correlation & Sig. \\
\hline Low economic development & 184 & 0.11 & $>0.001$ \\
\hline \multicolumn{4}{|l|}{ Table 6. Goodness of Fit Indices } \\
\hline \multicolumn{2}{|l|}{ Variables } & & Value \\
\hline \multicolumn{2}{|l|}{ Chi-square $\left(\chi^{2}\right)$} & & 0.12 \\
\hline \multicolumn{2}{|l|}{ Degree of freedom (df) } & & 16 \\
\hline \multicolumn{2}{|l|}{ Goodness of fit index (GFI) } & & 0.97 \\
\hline \multicolumn{2}{|c|}{ Adjusted goodness of fit index (AGFI) } & & 0.93 \\
\hline \multicolumn{2}{|l|}{ Normed fit index (NFI) } & & 0.96 \\
\hline \multicolumn{3}{|c|}{ Root mean square error of approximation (RMSEA) } & 0.003 \\
\hline \multicolumn{3}{|c|}{ 90\% Confidence interval for RMSEA } & 0.09 \\
\hline \multicolumn{3}{|l|}{ Critical value } & 0.32 \\
\hline \multicolumn{3}{|l|}{ Incremental fit index (IFI) } & 0.99 \\
\hline \multicolumn{3}{|l|}{ Relative fit index (RFI) } & 0.94 \\
\hline \multicolumn{3}{|c|}{ Minimum fit function Chi-square } & $2.32(\mathrm{P}=0.25)$ \\
\hline \multicolumn{3}{|c|}{ Normal theory weighted least squares Chi-square } & $4.77(\mathrm{P}=0.32)$ \\
\hline \multicolumn{3}{|c|}{ Estimated non-centrality parameter (NCP) } & 1.77 \\
\hline \multicolumn{3}{|l|}{ 90\% Confidence interval for NPC } & 14.4 \\
\hline \multicolumn{2}{|l|}{ Minimum fit function value } & & 0.12 \\
\hline \multicolumn{2}{|l|}{ Comparative fit index (CFI) } & & 0.99 \\
\hline
\end{tabular}

ity and capital deepening. The present findings are consistent with results reported in Najafi et al., Rumble, Jorgenson and Stiroh, Lee and Khatri, and Nour (10, 11, 17-19, 21, $24,25,27,30)$. Each of these mentioned studies reported a positive effect of ICT and new technologies on economic growth and development.

The results also show a strong correlation between distance education and high economic development $(\mathrm{r}=$ $0.441 ; \mathrm{P}=0.000)$. Distance education reduces costs of education and takes away the need for a full-time faculty, motivates students for lifelong learning and increases efficiency, effectiveness and productivity; thus contributing to strong economic growth and development. This is consistent with the results of Rumble and Jorgenson and Stiroh $(18,21)$.

Results also show a moderate correlation between distance education and average economic development ( $\mathrm{r}$ $=0.218 ; \mathrm{P}=0.000)$. Using hypertexts and hyperlinks to produce content, using PowerPoint for presentations and videoconferencing and e-mails for communication can reduce the costs of education and increase capital deepening. This is consistent with the results of Najafi et al. and Rumble (11, 18).

There was no significant correlation between distance education and low economic development $(\mathrm{r}=0.112 ; \mathrm{P}=$ 0.04). This result is consistent with the results of Pohjola and Schreyer who reported a positive effect of ICT on economic growth $(20,24)$. It must be noted that the present research was conducted in a developing country with a lack of ICT and infrastructure for distance education. Finally, results of SEM showed that the proposed model was a good fit to the data and that there was a causal relationship between distance education and economic development $\left(\chi^{2} / \mathrm{df}=0.764 ; \mathrm{RMSEA}=0.002 ; \mathrm{GFI}=0.97 ; \mathrm{AGFI}=0.93\right)$. It can be concluded that proper design and management of distance education and its components such as interaction, facilities and technology can promote innovation, creativity, efficiency, effectiveness, productivity; it can also facilitate capital deepening. This relationship is already well established in many developed countries but it may fail in less developed countries due to a lack of ICT and infrastructure for distance education. Thus it is recommended that investment be made in developing physical, hardware and software infrastructure to allow for more effective implementation of distance education and e-learning. It is also imperative to promote a culture of using ICT in academic settings as a main component of development in advanced countries.

\section{Acknowledgments}

The authors express their gratitude to all the experts of the Media Journal. 


\section{Footnotes}

Authors' Contribution: Mohammad Ali Javadi Bura and Mehran Farajollahi contributed to editing the paper.

Conflict of Interests: There is no conflict of interest. This study is an independent effort and no grants has been received from the university that is studied here (i.e. Payame Noor University). Also the authors have no financial interest in this university, nor do they hold any of its shares.

\section{References}

1. Zofan S, Lotfipoor K. Instructional media for classroom [In Persian]. Tehran: SAMT Publication; 2001.

2. Makhmali H. Knowledge management, human-centered development [In Persian]. Q J Manag Tomorrow. 2005;3(9):10-21.

3. Wolf S, editor. Determinants and impact of ICT use for African SMEs: Implications for rural South Africa. Center for Development Research (ZEF Bonn). Trade and Industrial Policy Strategies (TIPS), Annual Forum at Misty Hills, Mulderdrift (10-12 sept 2001). 2001; Paris.

4. Nazarzadeh M. Adult education and sustainable development. J Sci Commun. 2008;10(1):32-41.

5. Betts K. Online human touch (OHT) training \& support: A conceptual framework to increase faculty and adjunct faculty engagement, connectivity, and retention in online education, part 2.J Online Learn Teach. 2009;5(1):29-48.

6. Ebadi RE. Learning and education [In Persian]. Tehran: Aftbe mar publication; 2004. p. 47.

7. Javadi M, Najafi H, Farajollahi M. Factors affecting education quality; a case study in the higher education center of Tehran [In Persian]. Mag E Learn Distr in Acad. 2013;4(2):33-8.

8. UNESCO . Distance and open learning: Strategically and economical approach. ; 2002.

9. Ebrahimzadeh I. Transfer from traditional university to university: Innovation and challenge of change [In Persian]. Res High Educ Program. 2007;8(43):7-14.

10. Paksoy P. Use of global distance education program in educational goals of airline. Procedia Soc Behav Sci. 2015;177:372-8. doi 10.1016/j.sbspro.2015.02.365.

11. Najafi H, Farajollahi M, Norozzadeh R, Sarmadi M. A Study of the role of distance education on human resource development in the stu- dents of payame noor university (Iran) [In Persian]. Res Curriculum Plann. 2012;9(8):60-73.

12. Soltani E. The role of information technology in human resource development [In Persian]. Tadbir Monthly. 2004;14(138):43-52.

13. Leshkari M. Economics and planning [In Persian]. Tehran: Payame Noor University Publication; 2010. p. 49.

14. Mousavi Y. Economic development and planning [In Persian]. Tehran: PNU Press; 2007. p. 87

15. Tjaden GS. Measuring the information age business. Technol Anal $\&$ Strat Manage. 1996;8(3):233-46.

16. Qelij V. Principles and requirements of the development model is part of maintenance manpower. Q Strat. 2009;7(2):18.

17. Estevão M, Levy J. The new economy in France: Development and prospects. France Select Issu. 2000.

18. Rumble G, Evans T, Haughey M, Murphy D. Economic models of distance education. Emerald Group Publishing: Bingley, UK; 2008.

19. Srite M, Thatcher JB, Galy E. Does within-culture variation matter? An empirical study of computer usage. J Glob Inf Manag. 2008;16(1):1-25. doi: 10.4018/jgim.2008010101.

20. Pahjola F. Information technology and economic development. Oxford: Oxford University Press; 1998.

21. Jorgenson DW, Stiroh KJ. Raising the speed limit: U.S. Economic growth in the information age. Brookings Pap Econ Act. 2000;2000(1):125-10. doi: 10.1353/eca.2000.0008.

22. Quah D. Digital goods and the new economy. $2003: 19$.

23. Garrison DR. E-learning in the 21st century: A framework for research and practice. Taylor \& Francis; 2011

24. Schreyer P. The contribution of information and communication technology to output growth. 2000

25. Talati R. The impact of ICT globalization on economic growth in the members of the organization of Islamic cooperation (OIC) [In Persian], 98-109. Tehran: University of Tehran; 2006.

26. Rena R. Educational development in Eritrea. Asmara Eritrea Profi. 2004;11(12):6.

27. Nour SSOM, editor. The Impact of ICT on economic development in the Arab World: A comparative study of Egypt and the Gulf countries. Economic Research Forum Working Papers. 2002; .

28. Haacker M, Morsink J. You say you want a revolution: information technology and growth. International Monetary Fund; 2002.

29. Kordes L. The new economy in the United Kingdom, IMF country report. London: Fulmar; 2001

30. Lee MIH, Khatri Y. Information technology and productivity growth in Asia. International Monetary Fund; 2003 